\title{
Eotaxin protein and gene expression in guinea-pig lungs: constitutive expression and upregulation after allergen challenge
}

\author{
D. Li*, D. Wang*, D.A. Griffiths-Johnson+, T.N.C. Wells**, \\ T.J. Williams ${ }^{+}$, P.J. Jose ${ }^{+}$, P.K. Jeffery*
}

Eotaxin protein and gene expression in guinea-pig lungs: constitutive expression and upregulation after allergen challenge. D. Li, D. Wang, D.A. Griffiths-Johnson, T.N.C. Wells, T.J. Williams, P.J. Jose, P.K. Jeffery. (CERS Journals Ltd 1997.

ABSTRACT: Eotaxin is an eosinophil-specific chemoattractant originally identified in bronchoalveolar lavage fluid after allergen challenge of sensitized guineapigs. We have determined and quantified for the first time the cellular sources of guinea-pig lung eotaxin and localized gene expression in structural cells of large and small airways and in alveolar macrophages.

We used anti-guinea-pig eotaxin monoclonal and polyclonal antibodies and a complementary ribonucleic acid (cRNA) probe to detect eotaxin protein and cytoplasmic messenger ribonucleic acid (mRNA) transcripts by the techniques of immunohistochemistry and in situ hybridization in: 1) naive; 2) ovalbumin-sensitized/ saline-exposed; and 3) ovalbumin-sensitized/ovalbumin-challenged animals $(n=5$ for each group).

Compared with the naive animals, there was a fivefold increase of eotaxin protein and a 25 fold upregulation of eotaxin gene expression in the airway epithelium $3 \mathrm{~h}$ after ovalbumin challenge of sensitized animals $(\mathrm{p}<0.001)$. The average percentages of alveolar macrophages staining for eotaxin protein and mRNA in the naive animals were approximately 30 and $10 \%$ respectively: both increased significantly in the sensitized/ovalbumin-challenged animals to 78 and $57 \%$, respectively $(p<0.0001)$. Compared with the naive animals, the procedure of sensitization and saline exposure significantly increased eotaxin gene expression in both bronchial epithelium and alveolar macrophages $(p<0.01)$ : the upregulation at these two sites showed a strong positive association ( $\mathrm{rcorr}=0.95 ; \mathrm{p}<0.0001)$.

The results indicate that there are multiple cellular sources of guinea-pig lungderived eotaxin, including bronchial and bronchiolar epithelial cells, airway smooth muscle, bronchial vascular endothelium, and chondrocytes and alveolar macrophages, and that there are relatively rapid and marked increases of eotaxin protein and gene expression in airway epithelium and alveolar macrophages following allergen challenge.

Eur Respir J 1997; 10: 1946-1954.

Airway wall eosinophilia is a key characteristic of asthma and of the allergic response in a variety of tissues [1-6]. Whilst no animal model demonstrates the associated thickening of the reticular basement membrane and remodelling process seen in mild and severe asthma respectively [7,8], the guinea-pig model of acute and late phase reactions to allergen challenge provides a useful experimental means of investigating the inflammatory mediators of importance in allergic reactions [9]. Following their recruitment to tissues, activated eosinophils release preformed toxic cationic granule proteins, such as major basic protein, eosinophil cationic protein and eosinophil peroxidase, which are thought to damage the airway mucosa and lead to the airways hyperresponsiveness of asthma [10-12]. It is probable that understanding and targeting the process of eosinophil tissue recruitment and activation will assist the development of new and specific anti-inflammatory and anti-allergic drugs [6].
*Lung Pathology Unit and +Dept of Applied Pharmacology, Imperial College School of Medicine at the National Heart and Lung Institute, Dovehouse Street, London SW3 6LY, UK. **Geneva Biomedical Research Institute, Glaxo Wellcome Research and Development S.A., Geneva, Switzerland.

Correspondence: P.K. Jeffery

Lung Pathology Unit

Royal Brompton Hospital

Sydney Street

London

SW3 6NP

UK

Keywords: Airway

allergy

asthma

eosinophils

eotaxin

Received: May 61997

Accepted after revision July 21997
A guinea-pig CC chemokine named eotaxin has been demonstrated with the capacity to recruit eosinophils, but not neutrophils or mononuclear cells, when instilled into the airways or injected into the guinea-pig skin [13-15]. Guinea-pig eotaxin complementary deoxyribonucleic acid (cDNA) and its mouse and human cDNA homologues have been cloned [14, 16-20]. Eotaxin messenger ribonucleic acid (mRNA) increases in the lungs $3 \mathrm{~h}$ after allergen challenge of sensitized guineapigs $[14,20]$ and in skin following injection of interleukin (IL)-4-producing tumours in the mouse [16].

Human eotaxin also appears to be an early response gene in cytokine-stimulated epithelial [21] and endothelial cells, and can be induced in peripheral blood eosinophils by IL-3 [19]. In guinea-pig and mouse models of allergic inflammation in vivo, eotaxin mRNA and eotaxin protein levels parallel the kinetics of eosinophil accumulation in bronchoalveolar lavage fluid (BALF) and the lung $[22,23]$. The effect of eotaxin on 
eosinophil recruitment appears to be a direct one since, in purified form, eotaxin attracts guinea-pig eosinophils both in vitro [13] and in guinea-pig skin in vivo where the effect is completely inhibited by an anti-eotaxin antibody [23].

Northern blot analyses have demonstrated that eotaxin mRNA is highly expressed in human small bowel and colon, at intermediate levels in heart, kidney and pancreas, and at low levels in lung, spleen, thymus, prostate, ovary, liver and skeletal muscle $[17,19]$. PONATH et al. [17] recently described a preliminary study of human nasal mucosa and polyp tissue in which eotaxin immunostaining was localized to surface ciliated columnar epithelium and to a variety of subepithelial leucocytes including tissue eosinophils. In the present quantitative histological study of guinea-pig airways and lung, monoclonal and polyclonal anti-guinea-pig eotaxin antibodies have been used in order to localize the sources of eotaxin protein. In addition, guinea-pig eotaxin complementary ribonucleic acid (cRNA) probes and the technique of in situ hybridization have been applied to detect intracellular mRNA transcripts indicative of the sites of gene expression for guinea-pig eotaxin. We demonstrate for the first time that guinea-pig eotaxin and its gene expression are present in a variety of structural cells present in the airway mucosa and also in alveolar macrophages. Furthermore, eotaxin expression is markedly up-regulated following intratracheal challenge of previously sensitized animals.

\section{Materials and methods}

\section{Animals}

Fifteen male Dunkin Hartley guinea-pigs purchased from Charles River (Margate, Kent, UK) were used in this study. They were divided into: 1) naive; 2) sensitized/saline-exposed; and 3) sensitized/ovalbumin-challenged groups ( $\mathrm{n}=5$ for each group). The procedures of sensitization of guinea-pigs with intraperitoneal ovalbumin and aerosol allergen challenge were as described previously [13-15]. All animals were killed with a barbiturate overdose $3 \mathrm{~h}$ after saline exposure or ovalbumin-challenge.

\section{Histology and immunohistochemistry}

Immediately after killing, the lungs were expanded with $4 \%$ paraformaldehyde (Sigma, Dorset, UK) in phosphate-buffered saline (PBS) via the trachea until the pleural margins became sharp, and fixed by immersion for $4 \mathrm{~h}$ at $4^{\circ} \mathrm{C}$, transferred into $15 \%$ sucrose in PBS and processed as paraffin blocks. Six micron thick sections were cut and mounted on poly-L-lysine (Sigma, Dorset, UK) coated slides. Haematoxylin and eosinstained sections were used to assess the morphological changes associated with sensitization and allergen challenge. For the immunohistological localization of eotaxin both alkaline phosphatase anti-alkaline phosphatase (APAAP) [24] and peroxidase antiperoxidase (PAP) [24] methods were used. Briefly, in the APAAP method, the primary monoclonal anti-guinea-pig eotaxin antibody (mouse clone 72-B, immunoglobulin (Ig) G2a isotype screened against guinea-pig eotaxin and showing cross reactivity by enzyme-linked immunosorbent assay (ELISA) with human eotaxin, (Geneva Biomedical Research Institute, Geneva, Switzerland)) was applied, at 1:25 dilution followed by the secondary rabbit antimouse (dilution 1: 25, (Z0109) Dako, Bucks, UK) and tertiary APAAP complex (1:50, (D0651) Dako, UK). New fuchsin substrate (K596, Dako, UK) was added according to manufacturer's recommendations and the sections were counterstained with haematoxylin. Negative control monoclonal antibody (mouse IgG2a antibody to Aspergillus niger glucose oxidase, dilution 1:25, Dako, UK) was used. For the PAP method, the slides were pretreated in $0.3 \%$ $\mathrm{H}_{2} \mathrm{O}_{2}$ in absolute ethanol to block endogenous staining and the primary polyclonal antibody (rabbit anti-guineapig eotaxin, dilution 1:100) was added and incubated for $1 \mathrm{~h}$ at room temperature. After washing in TRIS (hydroxymethyl) aminomethane-buffered saline (TBS), a second layer mouse anti-rabbit monoclonal antibody (IgG1, Dako, UK, dilution 1:50 (M0737)) was added, followed by a third layer rabbit anti-mouse antibody conjugated with horse radish peroxidase (dilution 1:50, (P0260) Dako, UK). Wherever the primary antibody detected eotaxin (AEC), 3-amino-9-ethylcarbazole substrate system ((K0697) Dako, UK) was used to produce a dark red precipitate. As negative control, normal rabbit IgG (reconstituted to give an IgG concentration equivalent to that of the primary antibody and also used at $1: 100$ dilution) was substituted for the primary antibody. The sections were counterstained with methyl green and mounted with glycergel ((C0563) Dako, UK).

\section{In situ hybridization (ISH)}

Plasmid pEo3122 in BK-CMV, containing a 777 base pair (bp) guinea-pig eotaxin cDNA [14], was linearized with EcoR I (Boehringer Mannheim, East Sussex, UK) and Xhol (Boehringer Mannheim, UK), and ribonucleic acid (RNA) polymerase T3 and T7 (Boehringer Mannheim, UK) were used respectively to produce digoxigeninlabelled sense and antisense RNA probes. ISH was carried out according to the method of MARTINEZ-MONTERO et al. [25] with minor modifications. Briefly, after deparaffinization, tissue sections were permeabilized with 1 $\mathrm{ug} \cdot \mathrm{mL}^{-1}$ proteinase $\mathrm{K}$ (Boehringer Mannheim, UK) for $10 \mathrm{~min}$ and postfixed in $2 \%$ paraformaldehyde for 5 min. Either sense or antisense $50 \mathrm{ng}$ RNA probes were applied to each section. Hybridization was performed at $42^{\circ} \mathrm{C}$ overnight. Stringent washing was carried out in $0.1 \times$ standard saline citrate (SSC), $0.1 \%$ sodium dodecyl sulphate (SDS) at $37^{\circ} \mathrm{C}$ followed by $20 \mu \mathrm{g} \cdot \mathrm{mL}^{-1} \mathrm{RNAse}$ A (Sigma, Dorset, UK) digestion to remove all unhybridized RNA. Chromogen development was carried out after incubation with sheep antidigoxigenin Fab fragment conjugated with alkaline phosphatase (Boehringer Mannheim, UK, dilution 1:200), washing in TBS and addition of buffer solution containing $0.33 \mathrm{mg} \cdot \mathrm{mL}^{-1}$ nitroblue tetrazolium and $0.16 \mathrm{mg} \cdot \mathrm{mL}^{-1}$ 5-bromo-4-chloro-3indolyl-phosphate (Boehringer Mannheim, UK) substrate with $1 \mathrm{mM}$ levamisole and kept in the dark overnight. The slides were counterstained with methyl green and mounted with aqueous mountant (BDH, Poole, UK). 


\section{Quantification and statistical analyses}

Quantification of the immuno- and ISH-positivity of the epithelium and alveolar macrophages was carried out for the: 1) naive; 2) sensitized/saline-exposed; and 3) sensitized/ovalbumin-challenged animals. Assisted image analysis of microscopic slides was performed by application of Apple Macintosh computer with National Institutes of Health Image 1.5 software (National Institute of Health, Bethesda, MD, USA). The percentage area of epithelium immunopositive for eotaxin protein or that positive by ISH was calculated after measurement of the total area of surface epithelium in all available intrapulmonary cartilaginous airways in one tissue section and that which was immunopositive expressed as percentage of the total. Total macrophage numbers and those positive for eotaxin protein or those which were mRNA positive were counted in the alveolar spaces of 10 randomly selected consecutive $260 \times 260$ $\mu \mathrm{m}$ fields of lung tissue and expressed as mean cell number per microscopic field. The percentage of the total number of macrophages which were positive was also calculated. As the data were normally distributed, all values were expressed as the mean \pm SEM. The StatView (Abacus Concepts Inc., Berkeley, CA, USA) software programme was used to assess the statistical significance of group differences by unpaired t-test. Fisher's correlation (rcorr) was applied to test the concordance of upregulation for eotaxin protein in large airway epithelium and the number of immunopositive alveolar macrophages: the test incorporates an $\mathrm{r}$ to $\mathrm{z}$ transformation to ensure normalization of the data. A p-value of less than 0.05 was taken as statistically significant and for simplicity four levels of significance are reported: $p<0.05 ; p<0.01 ; p<0.001 ;$ and $p<0.0001$. The counts of errors of repeat measurement by a single observer
(DL) expressed as the percentage coefficient of variation were 4.2 and $4.6 \%$ for counts of macrophages and measurements of epithelial areas, respectively.

\section{Results}

\section{Morphological changes}

In comparison with the naive animals, both the ovalbumin-sensitized/saline-exposed and sensitized/ovalbumin-challenged guinea-pig lungs showed eosinophil infiltration of airway epithelium and surrounding interstitial tissues by $3 \mathrm{~h}$ postchallenge. In comparison with the sensitized group, there was a more florid response in the allergen-challenged group. The eosinophilic infiltrate was associated with a lymphoedema localized to peribronchial and periarterial tissues in which neutrophils and mononuclear cells were also present. The airway mucosa was also infiltrated by inflammatory cells, most of which were eosinophils. There was no significant shedding of airway surface epithelium in any animal. Goblet cell hyperplasia was evident in large intrapulmonary airways. In small airways (i.e. bronchioli), there was evidence of epithelial hyperplasia and apparent contraction of the airways associated with obstruction of the airway lumina. The parenchyma of the lung was congested. Alveolar macrophages were scarce in the naive animals, the mean number ( \pm SEM) being $1.8 \pm 0.3$ per microscopic field. There was a significant, but small, increase in their number in sensitized/ saline-exposed animals to $4.1 \pm 0.5 \cdot$ field $^{-1}(p<0.05)$. However, in comparison with the sensitized/saline-exposed group, there was an approximately fivefold increase in their number to $19.0 \pm 1.6 \cdot$ field $^{-1}$ in the sensitized/ovalbumin-challenged animals $(\mathrm{p}<0.0001)$.

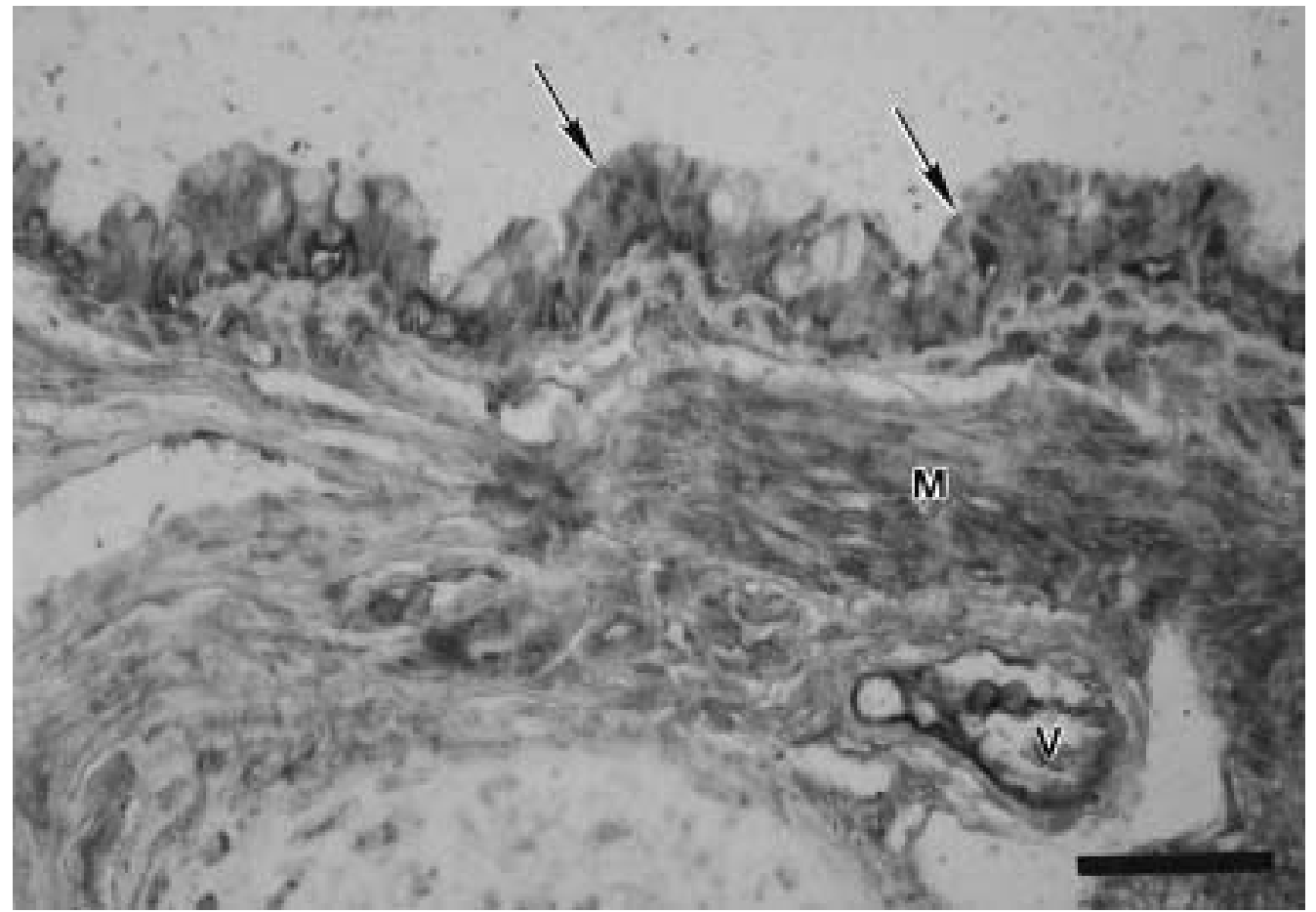

Fig. 1. - Large (cartilaginous) intrapulmonary airways immunostained for guinea-pig eotaxin using a polyclonal antibody and the peroxidase antiperoxidase technique. There is eotaxin protein localized to epithelial cells (arrows), bronchial smooth muscle (M) and the endothelium lining bronchial vessels $(\mathrm{V})$. (Internal scale bar $=100 \mu \mathrm{M}$ ). 


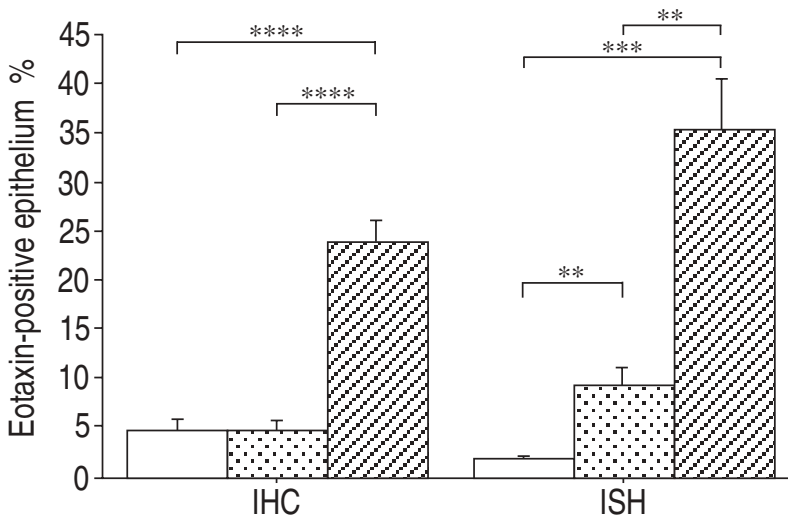

Fig. 2. - Per cent of epithelium eotaxin positive by immunohistochemistry (IHC) or messenger ribonucleic acid (mRNA) positivity by in situ hybridization (ISH). Values are mean \pm SEM. **: $\mathrm{p}<0.01$; *** p $<0.001$; $* * * *:$ p $<0.0001$ for ISH. $\square$ : naive; $\because \because$ : sensitized/salineexposed; $Z A$ : sensitized/ovalbumin-challenged.

\section{Eotaxin localization}

Immunohistochemical staining with both the mouse monoclonal and rabbit polyclonal anti-guinea-pig eotaxin antibodies showed positivity with identical localization, but the polyclonal antibody provided much stronger signals. The results for the polyclonal antibody were quantified and are presented herein.

In the large airways of the ovalbumin-challenged group, eotaxin positivity was present regularly in airway epithelium and appeared to be confined to ciliated cells and the basal aspects of the remaining epithelial cells (fig. 1 ). There was constitutive staining of the airways of the naive as well as the sensitized/saline-exposed animals: this included staining of airway epithelium, bronchial smooth muscle and chondrocytes. Approximately 5\% of the epithelial area stained for eotaxin: this was similar

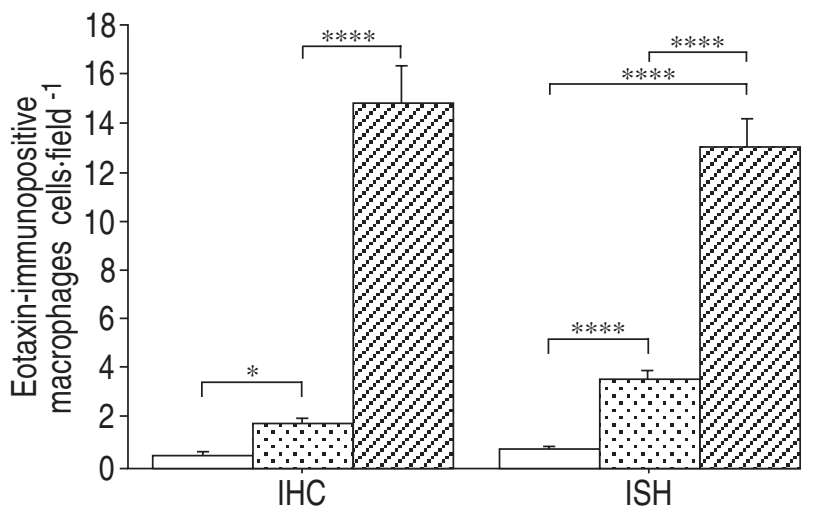

Fig. 4. - Mean numbers ( \pm SEM) of alveolar macrophages, per microscopic field, eotaxin-immunopositive by IHC for eotaxin or positive for eotaxin mRNA by ISH. *: p<0.05; ****: p<0.0001. $\square$ : naive; $\because \because$ : sensitized/saline-exposed; $C 2$ : sensitized/ovalbuminchallenged. For definitions, see legend to figure 2.

in both the naive and sensitized/saline-exposed groups. In comparison, there was an approximately fivefold increase of eotaxin protein to $23.9 \pm 2.0 \%$ in the sensitized/ ovalbumin-challenged group ( $\mathrm{p}<0.0001$ between sensitized/ovalbumin-challenged and sensitized/saline-exposed groups) (fig. 2). In contrast to the naive group, bronchial smooth muscle of both saline-exposed and allergenchallenged groups immunostained strongly whilst pulmonary vascular smooth muscle did not stain in any group. Bronchial vessels located within the airway wall were, however, positive. In bronchioli, positive staining was localized to nonciliated epithelial (Clara) cells but, in contrast to the large airway, there was a patchy distribution which made its quantification difficult (fig. 3). Figure 4 demonstrates the numbers of eotaxin-positive alveolar macrophages (expressed per microscopic field) in the three experimental groups. Compared with the naive group, there was a small but significant increase

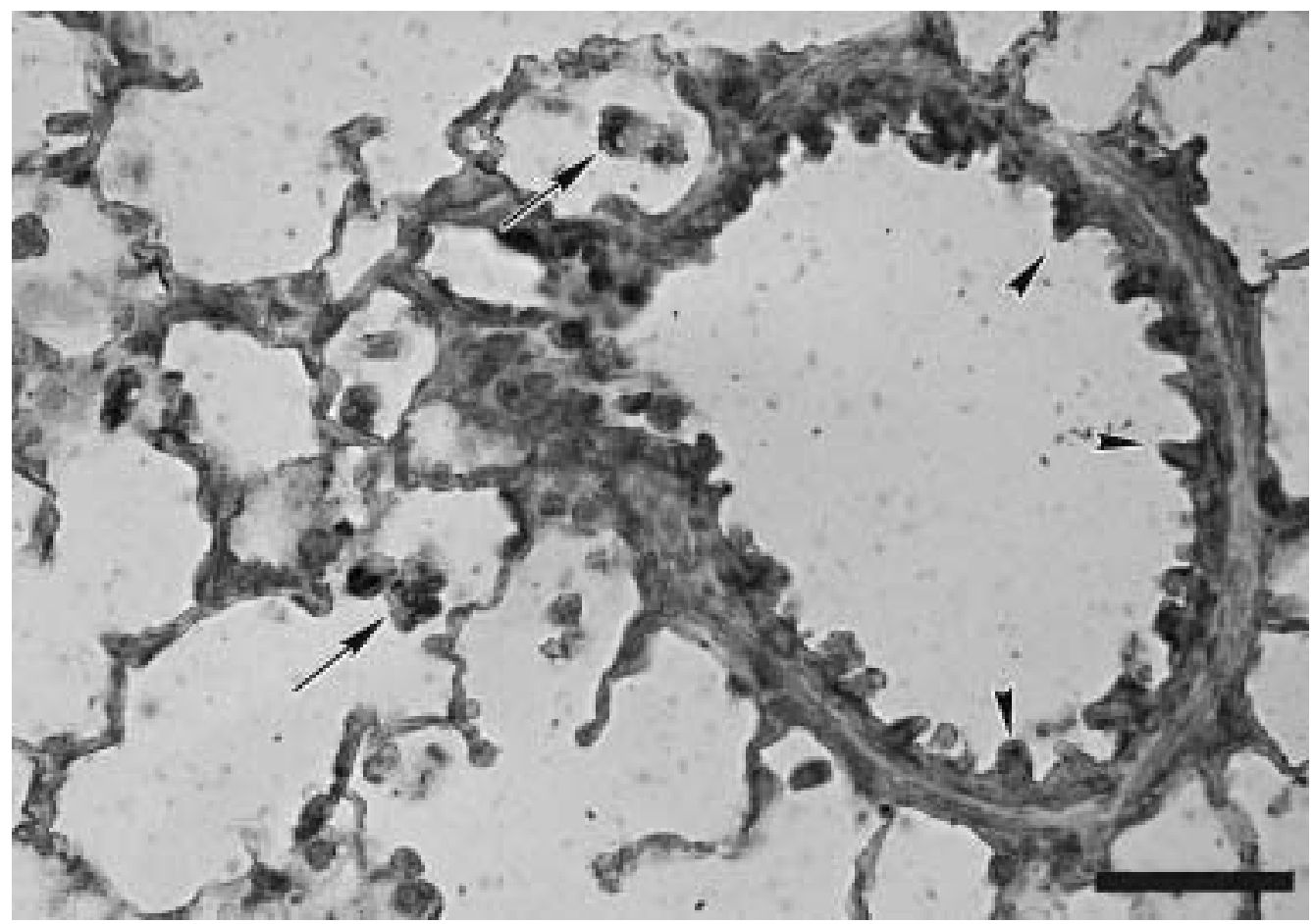

Fig. 3. - Bronchioli and lung parenchyma. Eotaxin immunoreactivity is present in nonciliated bronchiolar (Clara) cells (arrowheads), the surrounding bronchiolar smooth muscle and in alveolar macrophages (arrows). (Internal scale bar $=100 \mu \mathrm{M}$ ). 


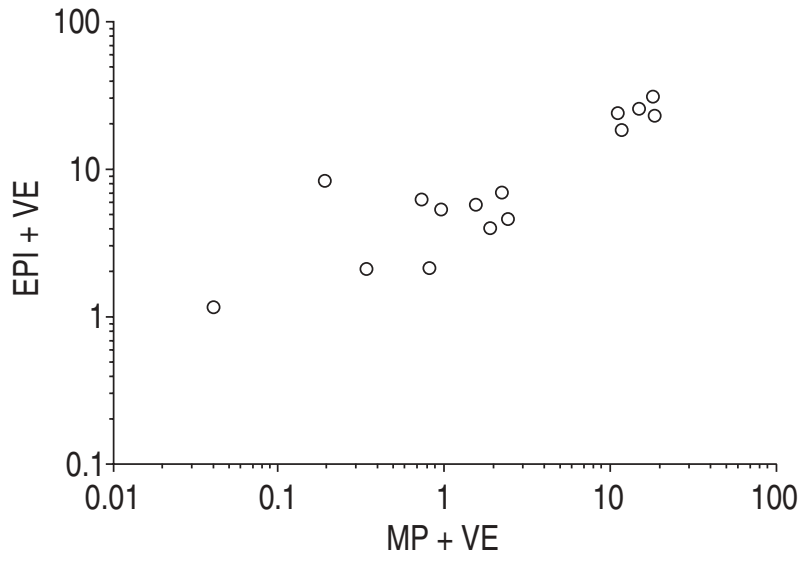

Fig. 5. - A scattergram showing the close relationship between the measurements of immunoexpression of eotaxin in large airway epithelium (EPI + VE) and alveolar macrophage (MP + VE) in the three groups of animals (Fisher's correlation $=0.95 ; \mathrm{p}<0.0001$ ).

in the mean number of eotaxin positive macrophages in the sensitized/saline-exposed group $(\mathrm{p}<0.05)$. In contrast, there was an approximately 30 fold increase in the ovalbumin-challenged group, which was significant when compared to either the sensitized/saline or naive groups $(\mathrm{p}<0.0001)$. As a percentage, $30-40 \%$ of the relatively few alveolar macrophages present in the naive and sensitized/saline-exposed animals stained for eotaxin. However, in the ovalbumin-challenged animals in which the alveolar macrophage number had increased, about $78 \%$ of the macrophages were immunostained for eotaxin $(\mathrm{p}<0.0001$ compared with the sensitized/salineexposed group) (fig. 3).

Comparison by correlation, of the up-regulation of eotaxin in large airway epithelium (determined by point counting) with that of the total numbers of alveolar macrophages staining for eotaxin resulted in the highly significant rcorr value of $0.95(\mathrm{p}<0.0001)$ (fig. 5). Occasionally, mononuclear cells present among the interstitial infiltrate stained for eotaxin. The negative control sections showed very weak diffuse staining not localized to any tissue structure.

\section{In situ hybridization}

ISH demonstrated constitutive eotaxin gene expression in both the naive and sensitized/saline-exposed animals, present in airway epithelial cells. Compared with the intensity of immunohistochemical staining, gene expression was relatively weak in airway smooth muscle (fig. 6). Approximately $1 \%$ (i.e. $1.4 \pm 0.5 \%$ ) of the epithelial area contained mRNA transcripts in the naive group. The sensitization/saline-exposure procedure significantly increased the epithelial area containing eotaxin mRNA transcripts about sixfold to $8.9 \pm 1.9 \%$ ( $\mathrm{p}<0.01$ compared with the naive group). Ovalbumin challenge of sensitized animals further significantly increased eotaxin gene expression to approximately four times that of the sensitized saline-exposed animals to $34.7 \pm 5.2 \%$ ( $\mathrm{p}<$ 0.01 and $\mathrm{p}<0.001$ compared with the sensitized/salineexposed and naive animals, respectively) (fig. 2). The mRNA was localized particularly to cells present at the base of epithelium (fig. 6). In bronchioli, Clara cells also showed strongly positive signals for eotaxin gene expression in the ovalbumin-challenged animals but, as with the immunoreactivity, its distribution was patchy (fig. 7).

Figure 4 demonstrates the numbers of alveolar macrophages positive for eotaxin mRNA. The ISH procedure showed a sixfold upregulation of eotaxin mRNA in response to sensitization $(\mathrm{p}<0.0001)$ : ovalbumin challenge was associated with a further fourfold increase

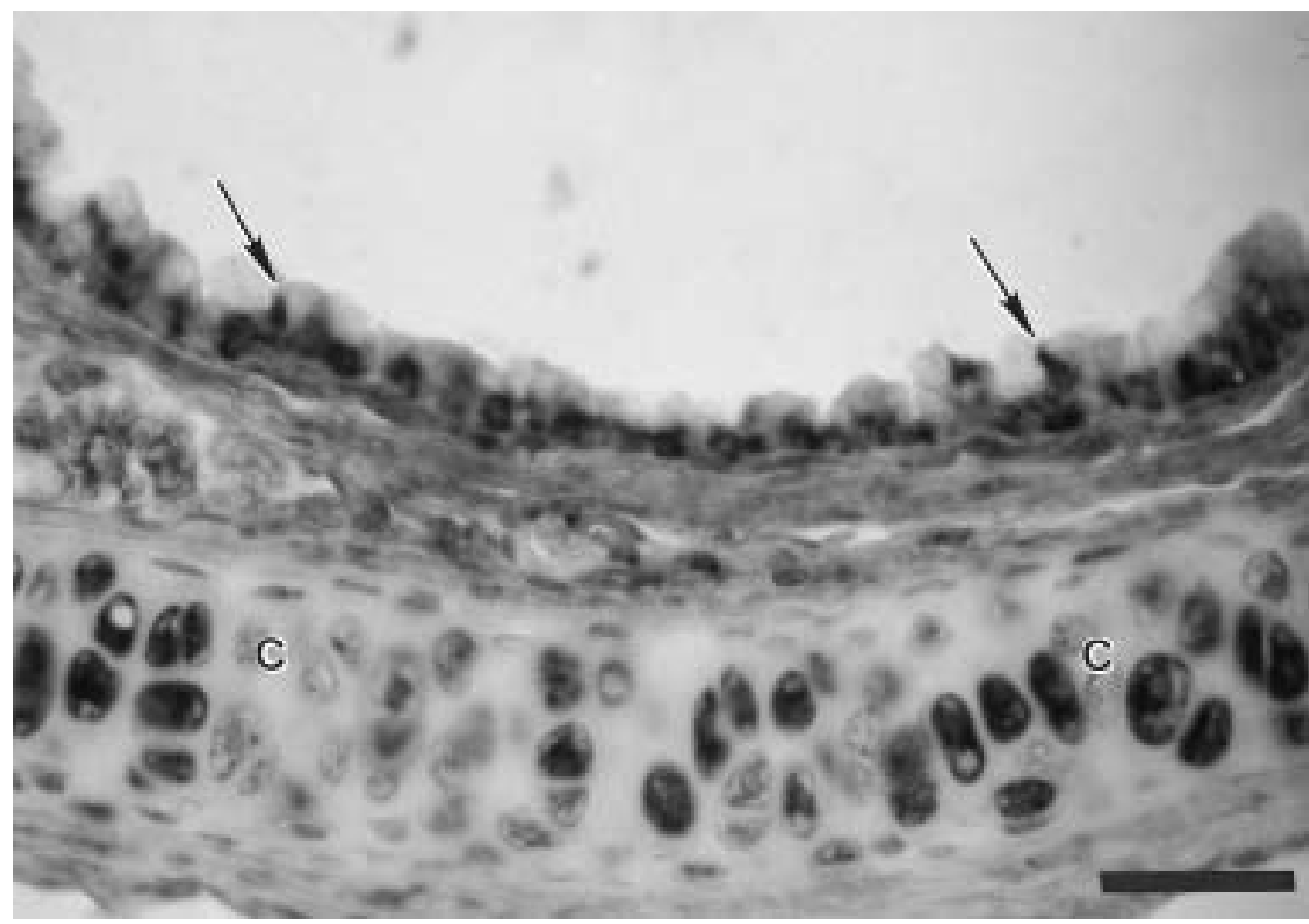

Fig. 6. - Nonisotopic in situ hybridization to show strong (blue/ black) intracellular localization of eotaxin messenger ribonucleic acid in epithelial cells (arrows) and chondrocytes of the underlying cartilage $(\mathrm{C})$. (Internal scale bar $=100 \mu \mathrm{M})$. 
$(\mathrm{p}<0.0001)$. As a percentage of the total, about $10 \%$ $(9.7 \pm 1.0 \%)$ of the relatively few alveolar macrophages present in the lungs of naive animals showed gene expression for eotaxin: this increased significantly to $36.6 \pm$ $1.0 \%(\mathrm{p}<0.0001)$ in the sensitized/saline-exposed animals. Ovalbumin challenge was associated with a further increase to $57.2 \pm 2.7 \%$, representing more than a fivefold increase over the naive animals $(p<0.0001$ for both saline-exposed and allergen-challenged groups compared with the naive animals and compared with each other).

In the oedematous interstitium, lymphocytes and mononuclear cells occasionally showed eotaxin gene expression. However, we did not observe ISH positivity in the eosinophils of either the ovalbumin-challenged or the saline-exposed animals. The sense ISH probe in both saline-exposed and allergen-challenged, and naive animals provided a "clean" negative control (figs. 8 and 9).

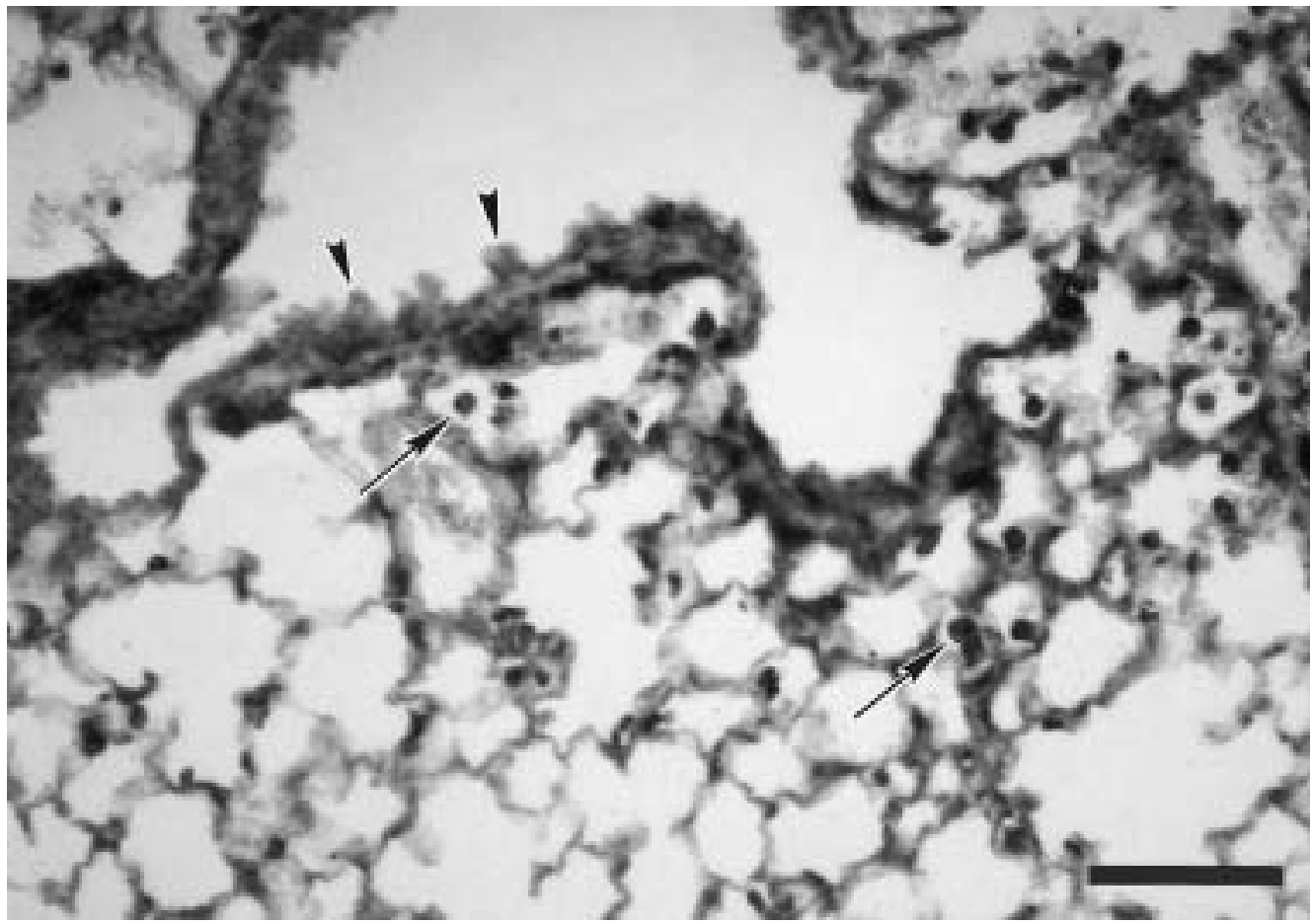

Fig. 7. - In situ hybridization showing a similar distribution of eotaxin messenger ribonucleic acid which is particularly strong in alveolar macrophages (arrows) and Clara cells (arrow heads). (Internal scale bar $=200 \mu \mathrm{M}$ ).

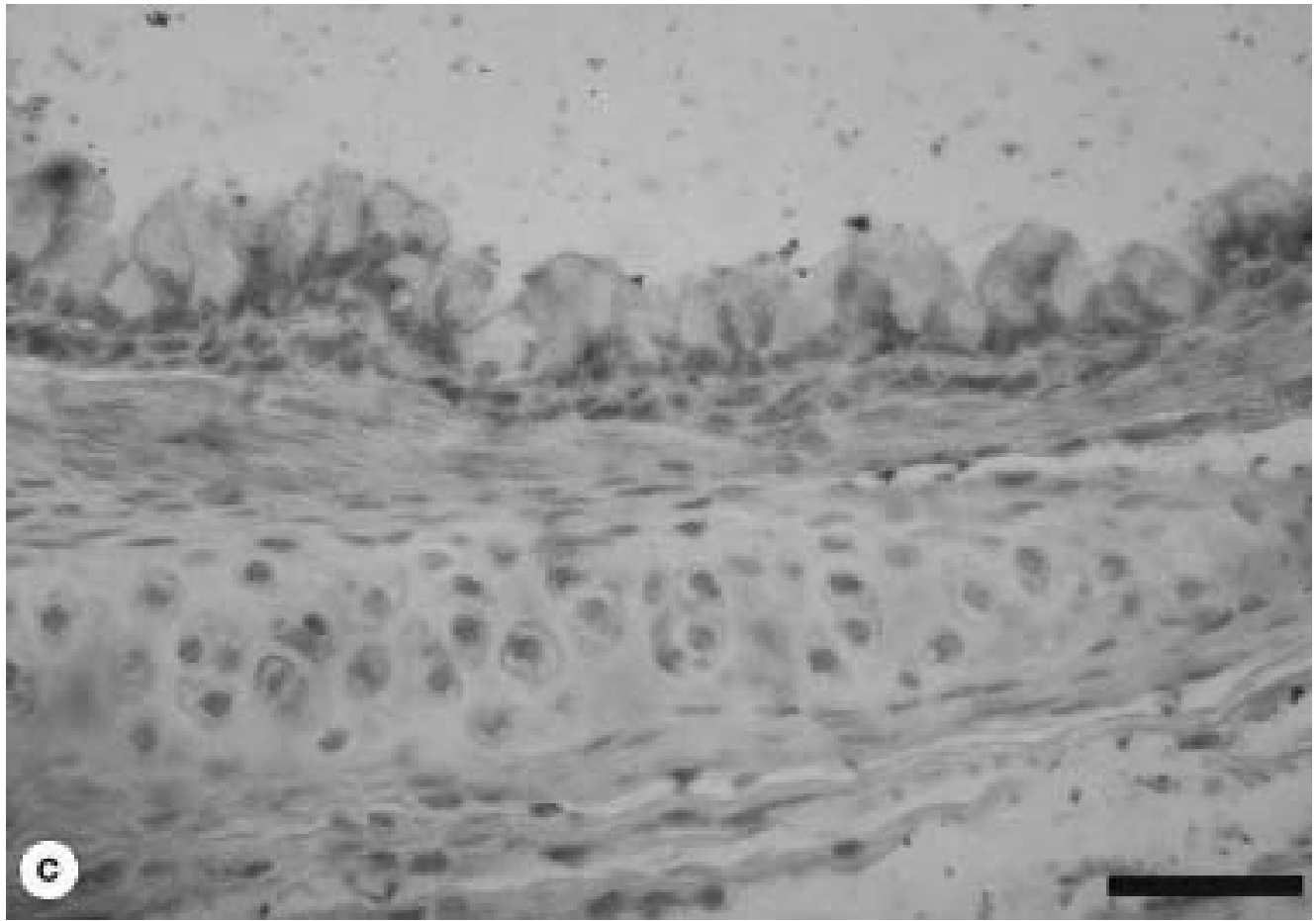

Fig. 8. - In situ hybridization sense (negative) control for the large airway. (Internal scale bar $=100 \mu \mathrm{M}$ ). 


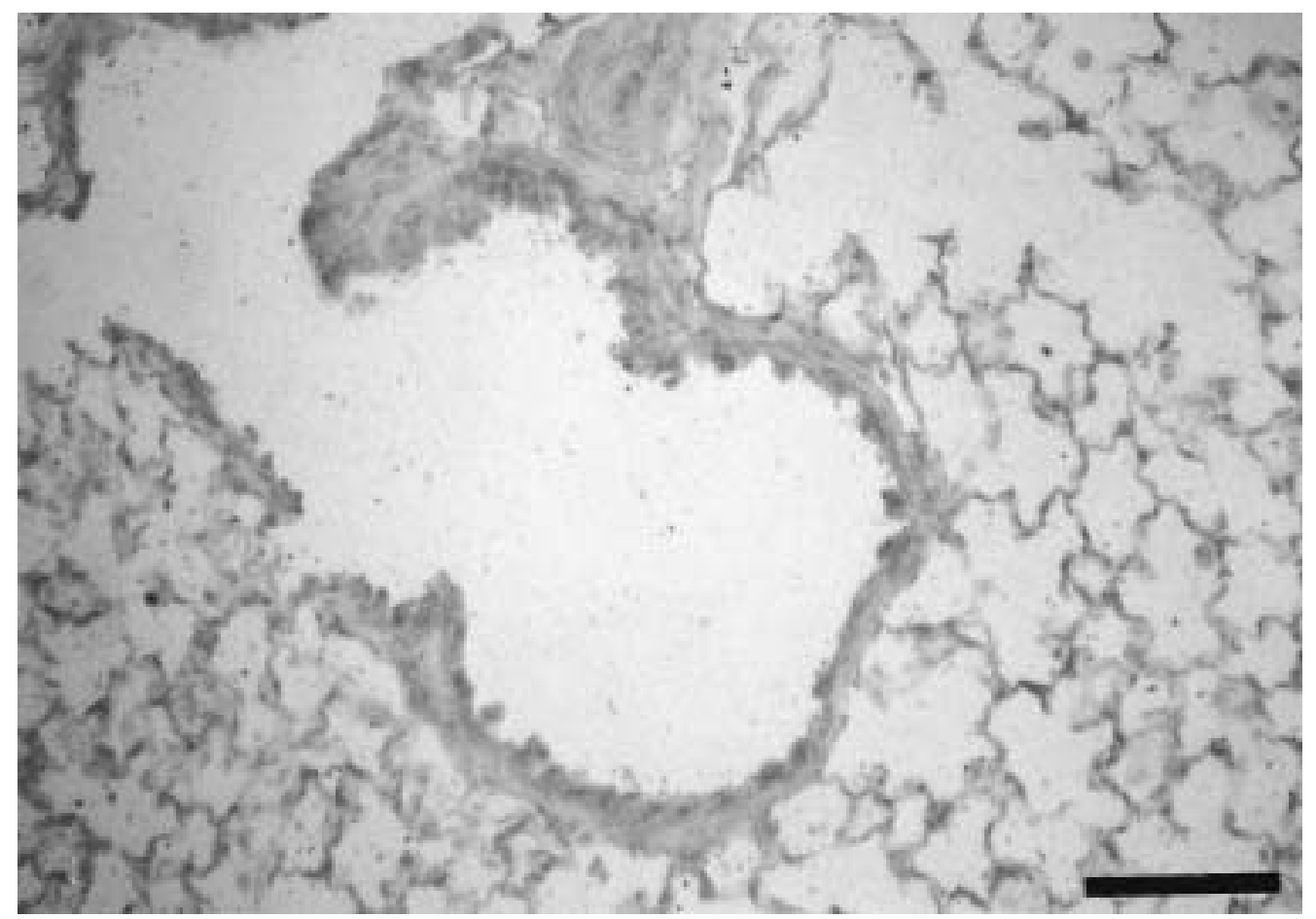

Fig. 9. - In situ hybridization sense (negative) control for the small airway and alveolus. (Internal scale bar $=200 \mu \mathrm{M}$ ).

\section{Discussion}

Eotaxin is a $\mathrm{CC}$ chemokine acting selectively on eosinophils $[14,15,17,19,20,22]$. In contrast, C5a, platelet-activating factor (PAF), monocyte chemotactic peptide-3 (MCP-3) and regulated on activation, normal T-cell expressed and secreted (RANTES) are also chemoattractants for eosinophils [26-30], but are less selective as they act additionally on other leucocytes. Eotaxin was originally purified from BALF of allergen-challenged guinea-pigs [13]. By Northern blot analysis, its gene expression has been shown to be up-regulated in ovalbumin-challenged guinea-pig lung $[14,20]$. However the origins and the cellular localization of constitutive and allergen-induced upregulation of eotaxin in the guineapig model of allergic inflammation are not known. We found a multicellular source of constitutive eotaxin protein and mRNA, co-localized in large and small airway epithelial cells, airway smooth muscle, bronchial capillaries, chondrocytes and occasionally in alveolar macrophages. Its constitutive uniform expression in the guinea-pig large airways and patchy distribution in small airways and lung is perhaps not surprising as this species is unusual in its tendency to large airway tissue eosinophilia. In addition, constitutive mRNA $[14,20]$ and protein have been reported previously in guinea-pig airways and lung by Northern blot and radioimmunoassay, respectively.

PONATH et al. [17] have recently reported eotaxin immunolocalization to human ciliated columnar nasal and polyp epithelium and also to underlying eosinophils, lymphocytes and macrophages. Our demonstration of constitutive eotaxin protein in guinea-pig ciliated bronchial epithelium was therefore expected and is largely in accord with the preliminary qualitative findings in human nasal mucosa. However, in contrast we did not find evidence of eotaxin protein or gene expression in guinea-pig pulmonary eosinophils. Our observations in the guinea-pig show that bronchiolar epithelium (putative Clara cells) also immunostain for eotaxin and express the mRNA encoding eotaxin, demonstrating for the first time that airway epithelium both synthesizes and stores this eosinophil chemoattractant. In agreement with our in vivo findings in the guinea-pig, there are reports using gel-based assays which demonstrate that the human BEAS-2B and A549 epithelial cell lines [19] can be induced by tumour necrosis factor (TNF)- $\alpha$, interferon (IFN)- $\gamma$ and IL- $1 \beta$ to express eotaxin mRNA, detectable at $0.5 \mathrm{~h}$ and peaking between 2-6 h, spanning the time point used in the present allergen-induced guinea-pig study $[19,21]$. The diverse secretory nature of epithelial cells has been recognized previously. Human bronchial epithelial cell lines can express mRNA for IL-6, IL-8 and granulocyte-macrophage colony-stimulating factor (GM-CSF) and they may also secrete these proinflammatory molecules [31] in response to stimulation by IL- $1 \beta$ and TNF- $\alpha$. Human nasal ciliated cells in cystic fibrosis may even express mucin genes [32]. The confirmation that airway epithelium can produce increased eotaxin protein provides further evidence for its potential key role in the initiation and control of allergic inflammation.

A variety of other cell types and tissues appear to have the capacity to express eotaxin mRNA or may show constitutive expression as, for example, following Northern blot analysis: small and large intestine; pancreas; heart; spleen; thymus and prostate [19]. In addition, we demonstrated that guinea-pig chondrocytes and bronchial smooth muscle also show constitutive protein and gene expression. The localization of eotaxin to chondrocytes probably explains the relatively high constitutive levels found in homogenates of guinea-pig trachea (Humbles et al., unpublished data). The expression of RANTES gene by cultures of airway smooth muscle 
is in keeping with reports of RANTES protein release [33] and our evidence for eotaxin expression demonstrates how bronchial smooth muscle may also play a proinflammatory effector role in the recruitment and activation of eosinophils. The number of activated eosinophils in hyperresponsive subjects is associated with the degree of airway responsiveness in asthma [2] and our findings demonstrate a way in which bronchial smooth muscle itself may influence airways responsiveness.

Our demonstration of the localization of eotaxin protein and mRNA to alveolar macrophages which not only increase in number in response to allergen but show a marked up-regulation of their gene expression and eotaxin protein is also novel. In respect of the eotaxin protein identified in the alveolar macrophages, the combination of the tenfold increase of macrophages after allergen challenge and the threefold increase in the percentage of eotaxin-positive cells results in a 30 fold increase of eotaxin-positive macrophages in the alveolar region compared with the naive animals. Macrophages as well as epithelial cells are ideally placed to sample allergen in inspired air and both are capable of expressing cell surface human leucocyte antigen-DR (HLADR) [34-36] and of responding in an antigen-specific fashion. Interestingly, the increase of eotaxin in macrophages showed a strong association with its upregulation in large airway epithelium ( $\mathrm{rcorr}=0.95 ; \mathrm{p}<0.0001$ ) indicating a co-ordinated allergic response throughout the respiratory tract. The relative expression and production of eotaxin by lumen-associated cells would determine the tissue gradient in airway or alveolus for eosinophil recruitment not only into the tissues, but also the driving force for their migration into the airway lumen. The production of eotaxin by both bronchiolar epithelium and alveolar macrophages may be of relevance to the reported observations of an alveolar involvement in the inflammation of asthma [37, 38].

However, the tissue eosinophilia of the guinea-pig response does not depend upon eotaxin alone. HumBLES et al. [39] have recently shown in the guinea-pig that anti-IL-5 and dexamethasone can inhibit tissue eosinophilia, yet eotaxin production remains uninhibited by these molecules. Up-regulation of guinea-pig eotaxin has recently been shown to be associated with an early increase of lung tissue eosinophils, measured by concentration of eosinophil peroxidase [23], and also to recruit more eosinophils in vivo in IL-5 pretreated animals [40]. Recent experiments using targeted gene disruption to deplete mice of eotaxin have demonstrated that eotaxin enhances the magnitude of the early, but not the late, phase recruitment of eosinophils and that it may contribute both to the generation of peripheral blood eosinophilia and the recruitment of eosinophils to tissue [41]. In addition, $\mathrm{TNF}-\alpha$ appears to be required to enhance vascular retention of the eotaxin-stimulated eosinophils via expression of their surface very late activation antigen-4 (VLA-4) ligand [42] and both IL-1$\alpha$ and TNF- $\alpha$ appear to be important early response molecules which up-regulate expression of eotaxin itself $[18,19]$. Mucosal mast cells may be the cell of origin for these proinflammatory molecules [19] and in this way may act as an important cell to trigger eotaxin expression and initiate eosinophil recruitment. Once produced, eotaxin may activate eosinophils to produce a variety of cytokines including IL-5 [43], inducing a proinflammatory positive cycle. The observation that human peripheral blood eosinophils may be induced by IL-3 to express significant amounts of eotaxin mRNA [19], and that tissue eosinophils may express the protein [17], is of interest. We did not, however, localize either eotaxin protein or mRNA to the allergen-induced recruitment of eosinophils in our guinea-pig model of acute allergic inflammation.

In conclusion, whilst the $\mathrm{T}$ helper- 2 cell response involves interleukin-4 and interleukin-5, the production of tissue eotaxin from a variety of cell sources may be of fundamental importance to the early tissue recruitment and activation of eosinophils [40] which characterizes the allergic inflammation of asthma and other eosinophilic conditions. The localization of eotaxin production is important not only to our understanding of the basic mechanisms of tissue eosinophilia and tissue damage but also to the design of drug delivery which can now target the specific cells that generate the signal responsible for the selective recruitment of eosinophils. We have shown that the cellular sources are multiple and, following challenge, both airway epithelial cells and alveolar macrophages exhibit marked increases in their eotaxin gene expression and synthesis of this novel protein: these should now be included as candidate target cells for the prevention or treatment of airway and lung eosinophilia.

Acknowledgements: The authors thank Glaxo-Wellcome, the Wellcome Trust and the National Asthma Campaign, UK for their support. They are grateful to A. Rogers for technical assistance and L. Oscar for secretarial assistance.

\section{References}

1. Azzawi M, Bradley B, Jeffery PK, et al. Identification of activated T-lymphocytes and eosinophils in bronchial biopsies in stable atopic asthma. Am Rev Respir Dis 1990; 142: 1407-1413.

2. Bradley BL, Azzawi M, Jacobson M, et al. Eosinophils, T-lymphocytes, mast cells, neutrophils and macrophages in bronchial biopsies from atopic asthmatics: comparison with atopic non-asthma and relationship to bronchial hyperresponsiveness. J Allergy Clin Immunol 1991; 88: 661-674.

3. Djukanovic R, Wilson JW, Britten KM, et al. Quantitation of mast cells and eosinophils in the bronchial mucosa of symptomatic atopic asthmatics and healthy control subjects using immunohistochemistry. Am Rev Respir Dis 1990; 142: 863-871.

4. Azzawi M, Johnston PW, Majumdar S, Kay AB, Jeffery PK. T-lymphocytes and activated eosinophils in asthma and cystic fibrosis. Am Rev Respir Dis 1992; 145: 14771482 .

5. Corrigan CJ, Kay AB. T-cells and eosinophils in the pathogenesis of asthma. Immunology Today 1992; 13: 501-506.

6. Busse WW, Sedgwick JB, Jarjour NN, Calhoun WJ. Eosinophils and basophils in allergic airway inflammation. J Allergy Clin Immunol 1994; 94: 1250-1254.

7. Jeffery PK. Pathology of asthma. Br Med Bull 1992; 48: 23-39.

8. Jeffery PK. Pathology of asthma. In: Kay AB, ed. Allergy and Allergic Diseases. Oxford, Blackwell Science Ltd, 1997; pp. 1412-1428.

9. Frew AJ, Moqbel R, Varley J, et al. T-lymphocytes and 
eosinophils in allergen-induced late phase asthmatic reactions in the guinea-pig. Am Rev Respir Dis 1990; 141: 407-413.

10. Venge P. Human eosinophil granule proteins: structure, function and release. In: Smith $\mathrm{H}$, Cook RM, Page C, eds. The Handbook of Immunopharmacology. London, Academic Press, 1993; pp. 43-56.

11. Filley WV, Holley KE, Kephart GM, Gleich GJ. Identification by immunofluorescence of eosinophil granule major basic protein in lung tissue of patients with bronchial asthma. Lancet 1982; 1: 11-16.

12. Motojima S, Frigas E, Loegering DA, Gleich GJ. Toxicity of eosinophil cationic protein for guinea-pig tracheal epithelium in vitro. Am Rev Respir Dis 1989; 139: 801-805.

13. Jose PJ, Griffiths-Johnson DA, Collins PD, et al. Eotaxin: a potent eosinophil chemoattractant cytokine detected in a guinea-pig model of allergic airways inflammation. J Exp Med 1994; 179: 881-887.

14. Jose PJ, Adcock IM, Griffiths-Johnson DA, et al. Eotaxin: cloning of an eosinophil chemoattractant cytokine and increased mRNA expression in allergen-challenged guineapig lungs. Biochem Biophys Res Commun 1994; 205: 788-794.

15. Griffiths-Johnson DA, Collins PD, Rossi AG, Jose PJ, Williams TJ. The chemokine, eotaxin, activates guineapig eosinophils in vitro and causes their accumulation into the lung in vivo. Biochem Biophys Res Commun 1993; 197: 1167-1172.

16. Rothenberg ME, Luster AD, Leder P. Murine eotaxin: an eosinophil chemoattractant inducible in endothelial cells and in interleukin 4-induced tumor suppression. Proc Natl Acad Sci USA 1995; 92: 8960-8964.

17. Ponath PD, Qui S, Ringler DJ, et al. Cloning of the human eosinophil chemoattractant, eotaxin. J Clin Invest 1996; 97: 604-612.

18. Bartels J, Schluter C, Richter E, et al. Human dermal fibroblasts express eotaxin: molecular cloning, mRNA expression, and identification of eotaxin sequence variants. Biochem Biophy Res Commun 1996; 225: 1045-1051.

19. Garcia-Zepeda EA, Rothenberg ME, Ownbey RT, Celestin J, Leder P, Luster AD. Human eotaxin is a specific chemoattractant for eosinophil cells and provides a new mechanism to explain tissue eosinophilia. Nat Med 1996; 2: 449-456.

20. Rothenberg ME, Luster AD, Lilly CM, Drazen JM, Leder P. Constitutive and allergen-induced expression of eotaxin mRNA in the guinea-pig lung. J Exp Med 1995; 181: 1211-1216.

21. Lilly CM, Nakamura H, Kesselman H, et al. Expression of eotaxin by human lung epithelial cells. J Clin Invest 1997; 99: 1767-1773.

22. Gonzalo J-A, Jia G-Q, Aguirre V, et al. Mouse eotaxin expression parallels eosinophil accumulation during lung allergic inflammation but it is not restricted to a Th2-type response. Immunity 1996; 4: 1-14.

23. Humbles AA, Conroy DM, Marleau S, et al. Generation and action of an eosinophil-selective chemoattractant, eotaxin, in vivo. (Abstract). Am J Respir Crit Care Med 1996; 153: A219.

24. Robinson G, Ellis IO, MacLennan KA. Immunocytochemistry. In: Bancroft JD, Stevens A, eds. Theory and Practice of Histological Techniques. 3rd Edn. London, Churchill Livingstone, 1990; pp. 413-436.

25. Martinez-Montero JC, Herrington CS, Stickland J, et al. Model system for optimising mRNA non-isotopic in situ hybridisation: riboprobe detection of lysozyme mRNA in archival gut biopsy specimens. J Clin Pathol 1991; 44: 835-839.
26. Teran LM, Montefort S, Douglass J, Holgate ST. Neutrophil and eosinophil chemotaxins in asthma. $Q \mathrm{~J} \mathrm{Med}$ 1993; 86: 761-769.

27. Hansel TT, Braun RK, De Vries IJM, et al. Eosinophils and cytokines. In: New Drugs in Allergy and Asthma. Basel, Birkhauser Verlag, 1993; pp. 197-208.

28. Resnick MB, Weller PF. Mechanisms of eosinophil recruitment. Am J Respir Cell Mol Biol 1993; 8: 349-355.

29. Rot A, Krieger M, Brunner T, Bischoff SC, Schall TJ, Dahinden CA. RANTES and macrophage inflammatory protein $1 \mathrm{a}$ induce the migration and activation of normal human eosinophil granulocytes. J Exp Med 1992; 176: 1489-1495.

30. Dahinden CA, Geiser T, Brunner T, et al. Monocyte chemoattractant protein is a most effective basophil-and eosinophil-activating chemokine. J Exp Med 1994; 179: 751-756.

31. Cromwell O, Hamid Q, Corrigan CJ, et al. Expression and generation of interleukin-8, IL-6 and granulocyte-macrophage colony-stimulating factor by bronchial epithelial cells and enhancement by IL- $1 \beta$ and tumor necrosis factor-alpha. Immunology 1992; 77: 330-337.

32. Li D, Wang D, Majumdar S, et al. Localization and upregulation of mucin (MUC2) gene expression in human nasal biopsies of patients with cystic fibrosis. $J$ Pathol 1997; 181: 305-310.

33. John M, Hirst JS, Jose PJ, et al. Human airway smooth muscle cells express and release RANTES in response to Thelper-1 cytokines. J Immunol 1997; 158: 1841-1847.

34. Rossi GA, Sacco O, Balbi B, et al. Human ciliate bronchial epithelial cells: expression of the HLA-DR antigens and of HLA-DR alpha gene, modulation of the HLA-DR antigens by gamma-interferon and antigenpresenting function in the mixed leucocyte reaction. Am J Resp Cell Mol Biol 1990; 3: 431-439.

35. Gant VA, Hamblin AS. Human bronchoalveolar macrophage heterogeneity demonstrated by histochemistry, surface markers and phagocytosis. Clin Exp Immunol 1985; 60: 539-545.

36. Glanville AR, Tazelaar HD, Theodore J. The distribution of MHC class I and II antigens on bronchial epithelium. Am J Resp Cell Mol Biol 1991; 4: 320-329.

37. Renzi PM, Olivenstein R, Martin JG. Inflammatory cell populations in the airways and parenchyma after antigen challenge in the rat. Am Rev Respir Dis 1993; 147: 967-974.

38. Kraft M, Djukanovic R, Wilson S, Holgate ST, Martin RJ. Alveolar tissue inflammation in asthma. Am J Respir Crit Care Med 1996; 154: 1505-1510.

39. Humbles AA, Conroy DM, Marleau S, et al. Kinetics of eotaxin generation and its relationship to eosinophil accumulation in allergic airways disease: analysis in a guinea-pig model in vivo.J Exp Med 1997; 186(4): 601-612.

40. Collins PD, Marleau S, Griffiths-Johnson DA, Jose PJ, Williams TJ. Cooperation between interleukin-5 and the chemokine eotaxin to induce eosinophil accumulation in vivo. J Exp Med 1995; 182: 1169-1174.

41. Rothenberg ME, MacLean JA, Pearlman E, Luster AD, Leder P. Targeted disruption of the chemokine eotaxin partially reduces antigen-induced tissue eosinophilia. $J$ Exp Med 1997; 185: 785-790.

42. Burke-Gaffney A, Hellewell PG. Eotaxin stimulates eosinophil adhesion to human lung microvascular endothelial cells. Biochem Biophy Res Commun 1997; 227: 35-40.

43. Broide DH, Paine MM, Firestein GS. Eosinophils express interleukin 5 and granulocyte macrophage colony-stimulating factor mRNA at sites of allergic inflammation in asthmatic. J Clin Invest 1992; 90: 1414-1424. 